\title{
ZS Research Suare \\ The impacts of fuel price policies on air pollution: A case study of Tehran
}

\section{pouran raeissi}

Iran University of Medical Sciences

touraj harati ( $\nabla$ tourajharati2019@gmail.com )

Iran University of Medical Sciences https://orcid.org/0000-0002-6003-1445

mohammad hadian

iran University of Medical Sciences

\section{Sepehr Ahmadian}

Kansas university

\section{Kobra Farhadi}

Alzahra University

\section{Research article}

Keywords: Air pollution; Fuel price, Policy, Autoregressive distributed lag model

Posted Date: July 1st, 2020

DOI: https://doi.org/10.21203/rs.3.rs-30187/v2

License: (c) (i) This work is licensed under a Creative Commons Attribution 4.0 International License. Read Full License

Version of Record: A version of this preprint was published at Environmental Science and Pollution Research on September 22nd, 2021. See the published version at https://doi.org/10.1007/s11356-021-16550-2. 


\section{Abstract}

Background: This study aims to investigate the impacts of fuel price policies on the concentration of air pollutants emitted from the transport sector.

Methods: Autoregressive distributed lag (ARDL) estimation models were used to investigate the impacts of gasoline and diesel prices along with the weather and economic variables on the following traffic-related pollutants: Carbon monoxide (CO), Nitrogen dioxide $\left(\mathrm{NO}_{2}\right)$, and Particular matter 10 micrometers or less $\left(\mathrm{PM}_{10}\right)$.

Results: In the short term, one percent increase in gasoline prices leads to 0.02 and 0.012 percent decrease in the concentration of $\mathrm{CO}$ and $\mathrm{PM}_{10}$, respectively. In addition, in the short term, one percent increase in diesel prices leads to $0.008,0.02$, and 0.015 percent decrease in the concentration of $\mathrm{CO}, \mathrm{PM}_{10}$, and $\mathrm{NO}_{2}$, respectively. Results demonstrate that one percent increase in gasoline prices leads to 0.011 and 0.02 percent increase in $\mathrm{NO}_{2}$ concentration in the short term and long term, respectively. Fuel prices had a greater impact on air pollutant concentration in the long term than in the short term. In the long term, one percent increase in diesel prices leads to $0.011,0.024$, and 0.029 percent decrease in the concentration of $\mathrm{CO}, \mathrm{NO}_{2}$, and $\mathrm{PM}_{10}$, respectively.

Conclusion: Although fuel price increases lead to a significant reduction in air pollution concentration, other factors related to weather conditions (wind speed, temperature, and rainfall) as well as economic activities have a greater impact on air pollution. Therefore, other policies such as improving fuel quality and technology along with other economic policies can be more effective.

\section{Background}

Air pollution is a serious threat to public health and the environment, and it is estimated that large volumes of pollutants enter the environment each year (1). Nowadays, many major cities in the world are facing environmental problems, especially due to air pollution, which put the health of people at risk. According to public data, air pollution often has exceeded the World Health Organization (WHO) standards in these cities $(2,3)$. Today, almost half of the world's population live in cities with population congestion and verity of environmental problems (4).

For example, Tehran is one of the eight polluted cities in the world in term of air pollution. Although it has only $1.2 \%$ of the country's total area, it accounts for $20 \%$ of the country's total population, $40 \%$ of the industry and $85 \%$ of its total expertise. The main causes of Tehran's air pollution are motor vehicles and cars (more than $80 \%$ ). In addition, non-standard vehicles, incorrect pattern of transformation and fuel consumption, low quality of fuels, and growth of migration has resulted in an increasing trend of air pollution $(5,6)$. According to the statistics and reports of Iranian Air Quality Control Organization (IAQCO), most of Tehran's air pollutants are $\mathrm{CO}, \mathrm{PM}_{10}, \mathrm{NO}_{2}$, respectively (7). Among the different sectors in Iran, transportation have the most role in emission these pollutants; so that the transport sector alone produced $64 \%, 99 \%$, and $80 \%$ of the total $\mathrm{NO}_{\mathrm{X}}, \mathrm{CO}$, and $\mathrm{PM}_{2.5}$ or $\mathrm{PM}_{10}$ respectively (5).

Governments on the other hand, are always seeking to alleviate environmental pollution problems and negative effects of human activities on the environment by adopting different policies and programs. However, reducing air pollution due to traffic is very difficult because policies that aim to reduce vehicle usage are met with resistance from the powerful car lobby. Also, the contribution of many people to the creation of air pollution due to vehicle usage is another difficulty in reducing air pollution (8). 
However, the government has implemented various short and long- term policies and programs and dedicated huge amounts of budgeting to control air pollution in Tehran (6).

Old vehicle retirement programs, expansion of subway lines, and implementation of traffic restrictions in the city center are examples of strategies that have been implemented to control the air pollution. Meanwhile, the implementation of fuel pricing policies to reduce air pollution and control fuel consumption in Tehran, due to its low running costs, has always been a priority among various plans $(9,10)$.

Fuel price, as a potential factor could contribute to change the demand for fuel and consequently change the pollutants emission from vehicles. For example, taking public transport instead of private vehicles, substituting vehicles with higher rates of fuel consumption with vehicles with lower rates of fuel consumption, and decreasing the distance driven are some responses tend to decrease air pollutants concentration (11).

However, few studies have examined the effects of fuel price policies on air pollution. In two studies conducted by Ninpanit and Barnett and Knibbs, declare that implementation fuel policies and increase fuel price have played an important role in improving air quality and reducing emissions $(12,13)$.

Elimination of energy subsidies and the gradual rise in fossil fuel prices are some fuel pricing policies that have been implemented in recent years, could improve fuel consumption patterns and some pollutants like $\mathrm{CO}, \mathrm{NO}_{2}$, and $\mathrm{PM}_{10}$ emitted from the transport section. Therefore, as fuel prices rise, it can be expected that air pollution and emissions will decrease. This study aims to investigate the effects of gasoline and diesel fuel prices policies on the amount of pollutants $\left(\mathrm{CO}, \mathrm{NO}_{2}\right.$, and $\left.\mathrm{PM}_{10}\right)$ which are emitted from the transport sector.

\section{Methods}

\subsection{Data}

Tehran is the capital of the Islamic Republic of Iran (IRI) and is located in the north of the country. Tehran is the most populous city in Iran and western Asia. Tehran has had a permanent resident population of 8.73 million people in 2017 (14), and 13, 267,637 during working days. Also, Tehran is the $8^{\text {th }}$ polluted city in the world (15). The center of the city is on latitude $35^{\circ} 41^{\prime} \mathrm{N}$ and longitude $51^{\circ} 26^{\prime} \mathrm{E}$. Figure 1 shows the location of Iran, Tehran, and monitoring stations in the 22 districts of Tehran.

Monthly concentration of $\mathrm{CO}, \mathrm{NO}_{2}$, and $\mathrm{PM}_{10}$ were collected from Air Quality Control Company (AQCC) from March 21, 2009 to December 21, 2019. Figure 2 (a-c) shows the trends of monthly air pollutant changes during this study period.

The real prices for gasoline and diesel in Iran between January of 2009 to December of 2019, were used in this study (see Fig. 2 d). These data were collected from the National Iranian Oil Product Distribution Company (NIOPDC). This study used real fuel prices data; consequently, fuel price data's were expressed as consumer price index based on constant price of 2016.

Also, this study gathered monthly averages of weather data (rainfall, wind speed, and temperature) across 10 weather stations from Tehran meteorological organization.

In order to measure manufacturing production index and value added tax revenue, national data's were used. These variables gathered at constant 2016 prices from Central Bank of Islamic Republic of Iran. 


\subsection{Model framework}

Over time, it becomes increasingly important to examine the air pollution status and its related factors. Besides human activities, changes in the atmospheric status have an important role on the air pollution status.

In many cases, the effect of explanatory variables is associated with significant lags and researchers seek to examine the long-term effects of explanatory variables along with the short-term effects. To estimate and analyze long-term and short-term relationships between the variables under study, the autoregressive distributed lag (ARDL) method introduced by Pesaran et al. (16) in 2001 was used. In these models, the dependent variable (e.g. $\left.Y_{t}\right)$ is affected by its lags $\left(Y_{t-j}\right)$, other independent variables (e.g. $\left.X_{t}\right)$, and lags of independent variables $\left(X_{t-j}\right)$. The general framework of ARDL $(p, q)$ model is as follow: (see Equation 1 in the Supplemental Files)

Where $\mathrm{p}$ and $\mathrm{q}$ are the optimum lag for dependent variable and independent variables respectively. $B_{j}$ and $y_{j}$ are the model parameter.

Where $\mathrm{p}$ and $\mathrm{q}$ are the optimum lag for dependent variable and independent variables respectively. and are the model parameter.

At first, this method estimate the short-term relationship between variables. Then, to estimate long- term results, by including the trend of variables in the long term and the relationship between these trends, the model examines. In other words, considering the long-term trend of variables in estimates is the reason for the difference between shortterm and long-term estimates.

Hence, the following model was used to examine the impacts of fuel prices and atmospheric variables on air pollutant concentration: (see Equation 2 in the Supplementary Files)

Where, $\mathrm{m}$ denote month. $\mathrm{A}$ is a dependent variable and denotes air pollutant concentration. In this study, we estimate three model separately and $\mathrm{PM}_{10}, \mathrm{CO}$, and $\mathrm{NO}_{2}$ pollutants are dependent variable in each model. $\mathrm{P}$ is a vector for real fuel price per liter. In addition, $\mathrm{X}$ is a vector for control variables. In this model, logarithm of variable such as average monthly wind speed, total rainfall and temperature considered as control variables. Also, a public holidays dummy, and a linear time trend are considered as control variables. This study considered manufacturing production index and the value added tax revenue as other control variables. Dum represents dummy variable. $\varepsilon$ is an error term. Reasons for controlling these variables are described below.

Wind speed, temperature, and rainfall are considered due to their impacts on air pollutants concentration. There is evidence showing the influence of wind speed and rainfall on air pollutants concentration $(17,18)$. As the wind speed and rainfall increases, the concentration of pollutants reduce. Also, increase in the number of holidays and weekends in each month would lead to reduction for fuel demand followed by the reduction of air pollution emission. Furthermore, this study considers the number of holidays as a control variable. Commonly, people use fewer personal vehicles to get their children to school or to work in holidays.

MAP and VAT revenue used as a proxy for measuring the changes in manufacturing production activity and consumption spending respectively. In fact, increase in each of these two variables would likely lead to an increase in ambient air pollution.

With reference to the fact that the population and quality of fuels change gradually over time, time trend considered as a control variable for measuring factors in this model. Unfortunately, fuel quality in Iran has been decreasing 
overtime due to international economic sanctions; meanwhile, the population is growing gradually. Therefore, the concentration of pollutants expected to increase. In addition, this model uses a dummy variable to measure increasing fuel price shocks that occurred in five time periods $(2009 / 04,2010 / 12,2014 / 04,2015 / 03$, and 2019/10) by the government. All variables include in logarithm form in model. Table 1 provides a list of variables, abbreviations, and units used throughout the model framework.

Table 1. Definition of terms, units, and abbreviations.

\begin{tabular}{|c|c|c|c|}
\hline Abbreviation & Full term & Definition & Unit \\
\hline \multirow[t]{2}{*}{$\mathrm{CO}$} & Carbon monoxide & Average monthly concentration of carbon monoxide & \\
\hline & & & $\begin{array}{l}\text { parts per million } \\
\quad(\mathrm{ppm})\end{array}$ \\
\hline $\mathrm{NO}_{2}$ & Nitrogen dioxide & Average monthly concentration of nitrogen dioxide & $\begin{array}{l}\text { Parts per billion } \\
\qquad(\mathrm{ppb})\end{array}$ \\
\hline $\mathrm{PM}_{10}$ & $\begin{array}{l}\text { Particular matter } 10 \\
\text { micrometers or less }\end{array}$ & $\begin{array}{l}\text { Average monthly concentration of particular matter } 10 \\
\text { micrometers or less }\end{array}$ & $\begin{array}{c}\text { microgram } \\
\text { per cubic meter } \\
\qquad\left(\mu \mathrm{g} / \mathrm{m}^{3}\right)\end{array}$ \\
\hline GP & Gasoline price & Average monthly real gasoline price per liter & $\begin{array}{l}\text { Iranian Rials } \\
\text { (IRR) per liter }\end{array}$ \\
\hline $\mathrm{DP}$ & Diesel price & Average monthly real diesel price per liter & $\begin{array}{l}\text { Iranian Rials } \\
\text { (IRR) per liter }\end{array}$ \\
\hline Temp & Temperature & Average monthly temperature & Celsius \\
\hline Rain & Rainfall & Average monthly rainfall & millimeter (mm) \\
\hline MPI & $\begin{array}{l}\text { Manufacturing } \\
\text { production index }\end{array}$ & $\begin{array}{l}\text { is an economic indicator that measures the real production } \\
\text { output of manufacturing }\end{array}$ & - \\
\hline VAT & Value added tax & is a consumption tax placed on a product & Iranian Rials (IRR) \\
\hline Wind & wind speed & Average monthly wind speed & $\begin{array}{l}\text { Meter per second } \\
\qquad(\mathrm{m} / \mathrm{s})\end{array}$ \\
\hline Holi & $\begin{array}{l}\text { Number of holidays } \\
\text { and weekend days }\end{array}$ & Number of holidays and weekend days & - \\
\hline DUM & Dummy & $\begin{array}{l}\text { takes only the numerical values to indicate the effects of } \\
\text { some categorical effect (increasing fuel price shocks) }\end{array}$ & - \\
\hline
\end{tabular}

\section{Results}

\subsection{Monthly estimates}

The first step in analysis of longitudinal studies is the examination of the stationarity of variables. Due to high variation in investigated variables during the course of study, all variables were used in logarithmic form. To check variables stationarity, the Augmented Dickey-Fuller test was used. The null hypothesis in this test implies the existence of a single root for each variable, which in nature is a non-stationary variable. Consequently, this study carried out these unit root tests on the log of pollution (average across 19 stations), fuel prices, and weather variables with linear time trend. Table 2 represents the results of stationarity test. 
Table 2. Results of stationarity test.

\begin{tabular}{ccccc}
\hline Variable & & Test statistics $\left(\mathrm{p}^{\mathrm{c}}\right)$ & & Test result \\
\cline { 1 - 1 } \cline { 5 - 5 } $\mathrm{Ln}^{\mathrm{a}} \mathrm{CO}$ & & $-1.62(0.46)$ & & Non-stationary \\
$\Delta^{\mathrm{b}} \mathrm{Ln} \mathrm{CO}$ & & $-7.13(0.00)$ & & stationary \\
\cline { 1 - 1 } $\mathrm{Ln} \mathrm{NO}_{2}$ & & $-2.80(0.058)$ & & Non-stationary \\
\hline$\Delta \mathrm{Ln} \mathrm{NO}_{2}$ & & $-12.4(0.00)$ & & stationary \\
\hline Ln PM $_{10}$ & & $-4.67(0.00)$ & & stationary \\
\hline Ln GP & & $-2.40(0.14)$ & & Non-stationary \\
\hline$\Delta$ Ln GP & & $-11.66(0.00)$ & & stationary \\
\hline Ln DP & & $-2.31(0.16)$ & & Non-stationary \\
\hline$\Delta$ Ln DP & & $-11.45(0.00)$ & & stationary \\
\hline Ln Temp & & $-2.01(0.4)$ & & Non-stationary \\
\hline$\Delta$ Ln Temp & & $-5.31(0.00)$ & & stationary \\
\hline Ln Rain & & $-2.00(0.65)$ & & Non-stationary \\
\hline$\Delta$ Ln Rain & & $-2.33(0.00)$ & & stationary \\
\hline Ln wind & $-1.12(0.14)$ & & Non-stationary \\
\hline$\Delta$ Ln wind & $-2.11(0.00)$ & & stationary \\
\hline Holi & $-2.71(0.059)$ & & Non-stationary \\
\hline$\Delta$ Holi & $-12.4(0.00)$ & stationary \\
\hline
\end{tabular}

${ }^{a}$ denote logarithm; ${ }^{b}$ denote the difference between variable logarithm in time $t$ and $t-1 ;{ }^{c} \mathrm{P}$ value

According to the results in table 2, all variables become stationary after one- differentiating (I(1)) except for $\mathrm{PM}_{10}$. $\mathrm{PM}_{10}$ were stationary at level $(\mathrm{I}(0))$. Therefore, it can be concluded that the relationship between the time series is sufficient, so the results of the regression are to be true.

Since variables in this study, are a combination of different stationary (I (0) and I (1)), the use of the auto regressive distributed lag (ARDL) method is more preferable with respect to other methods. In this model, the Hannan-Quinn criterion (HQ) was used to determine the optimum length of lags. The optimum lags for variables in each models reported in parenthesis in table 3 . The optimum lags for models with $\mathrm{CO}, \mathrm{PM}_{10}$, and $\mathrm{NO}_{2}$ dependent variables were $(1,0,0,2,0,0,2,0,0,0,0),(1,0,0,1,0,0,2,0,0,0,0)$, and $(1,2,0,0,1,1,0,0,0,0,0)$. The first numbers in parenthesis refer to optimum lag number of dependent variables, and other numbers refer to independent variables optimum lags. The optimum lags for all dependent variables were one, so we included all dependent variables with one lag. In model with CO dependent variable, the optimum lags for variables "Ln Temp" and "Ln Trend" was two, so in this model we apply "Ln Temp (-1)", "Ln Temp (-2)", "Ln Trend (-1)", and "Ln Trend (-2)". In other hand, the optimum lag for other explanatory variables was zero, so we included these variables in non-lag form.

Table 3. Results of short-term estimations for models with three different pollutants $\left(\mathrm{CO}, \mathrm{NO}_{2}\right.$, and $\left.\mathrm{PM}_{10}\right)$ 


\begin{tabular}{|c|c|c|c|c|c|c|c|c|}
\hline \multirow{4}{*}{$\begin{array}{c}\begin{array}{c}\text { Dependent } \\
\text { variable }\end{array} \\
\text { Optimum lag }\end{array}$} & \multirow{2}{*}{\multicolumn{2}{|c|}{ Ln CO }} & \multirow{4}{*}{$\begin{array}{c}\begin{array}{c}\text { Dependent } \\
\text { variable }\end{array} \\
\text { Optimum lag }\end{array}$} & \multirow{2}{*}{\multicolumn{2}{|c|}{ Ln $\mathrm{PM}_{10}$}} & \multirow{4}{*}{$\begin{array}{c}\begin{array}{c}\text { Dependent } \\
\text { variable }\end{array} \\
\text { Optimum lag }\end{array}$} & \multirow{2}{*}{\multicolumn{2}{|c|}{ Ln $\mathrm{NO}_{2}$}} \\
\hline & & & & & & & & \\
\hline & \multicolumn{2}{|c|}{$\begin{array}{c}(1,0,0,2,0,0,2 \\
0,0,0,0)\end{array}$} & & \multicolumn{2}{|c|}{$\begin{array}{c}(1,0,0,1,0,0,2,0 \\
0,0,0)\end{array}$} & & \multicolumn{2}{|c|}{$\begin{array}{c}(1,2,0,0,1,1,0,0 \\
0,0,0)\end{array}$} \\
\hline & coefficient & $\begin{array}{c}\mathrm{t}- \\
\text { value } \\
(\mathrm{p})\end{array}$ & & Coefficient & $\begin{array}{c}\text { t-value } \\
\left(p^{\mathrm{a}}\right)\end{array}$ & & Coefficient & $\begin{array}{c}\text { t-value } \\
\left(p^{a}\right)\end{array}$ \\
\hline $\operatorname{Ln} \mathrm{CO}\left(-1^{\mathrm{b}}\right)$ & 0.48 & $\begin{array}{l}6.005 \\
(0.00)\end{array}$ & Ln $\mathrm{PM}_{10}\left(-1^{\mathrm{b}}\right)$ & 0.41 & $\begin{array}{l}5.005 \\
(0.00)\end{array}$ & $\operatorname{Ln} \mathrm{NO}_{2}\left(-1^{\mathrm{b}}\right)$ & 0.61 & $\begin{array}{c}8.77 \\
(0.00)\end{array}$ \\
\hline Ln MPI & 0.67 & $\begin{array}{l}-1.75 \\
(0.08)\end{array}$ & Ln MPI & 0.17 & $\begin{array}{l}-1.83 \\
(0.07)\end{array}$ & Ln MPI & 0.79 & $\begin{array}{c}0.97 \\
(0.33)\end{array}$ \\
\hline Ln Rain & 0.01 & $\begin{array}{c}2.39 \\
(0.11)\end{array}$ & Ln Rain & -0.007 & $\begin{array}{c}2.93 \\
(0.02)\end{array}$ & $\operatorname{Ln} \operatorname{MPI}\left(-1^{b}\right)$ & 0.36 & $\begin{array}{l}1.26 \\
(0.2)\end{array}$ \\
\hline Ln Temp & -0.006 & $\begin{array}{c}2.33 \\
(0.02)\end{array}$ & Ln Temp & -0.09 & $\begin{array}{c}3.33 \\
(0.01)\end{array}$ & $\operatorname{Ln} \operatorname{MPI}\left(-2^{b}\right)$ & -1.96 & $\begin{array}{l}-2.45 \\
(0.01)\end{array}$ \\
\hline Ln Temp $\left(-1^{b}\right)$ & -0.002 & $\begin{array}{l}-0.52 \\
(0.59)\end{array}$ & Ln Temp $\left(-1^{b}\right)$ & -0.002 & $\begin{array}{l}-0.52 \\
(0.59)\end{array}$ & Ln Rain & 0.01 & $\begin{array}{c}1.1 \\
(0.1)\end{array}$ \\
\hline Ln Temp $\left(-2^{b}\right)$ & 0.005 & $\begin{array}{c}1.78 \\
(0.07)\end{array}$ & Ln VAT & 0.04 & $\begin{array}{l}2.12 \\
(0.3)\end{array}$ & Ln Temp & -0.001 & $\begin{array}{c}1.29 \\
(0.19)\end{array}$ \\
\hline Ln VAT & 0.01 & $\begin{array}{l}-0.25 \\
(0.8)\end{array}$ & $\ln \mathrm{GP}$ & -0.012 & $\begin{array}{l}-1.97 \\
(0.05)\end{array}$ & Ln VAT & 1.39 & $\begin{array}{l}-1.51 \\
(0.13)\end{array}$ \\
\hline $\ln \mathrm{GP}$ & -0.02 & $\begin{array}{l}-1.97 \\
(0.05)\end{array}$ & Ln Trend & 0.05 & $\begin{array}{l}-2.23 \\
(0.2)\end{array}$ & Ln VAT $\left(-1^{b}\right)$ & 1.9 & $\begin{array}{c}2.03 \\
(0.04)\end{array}$ \\
\hline Ln Trend & 0.1 & $\begin{array}{l}-2.23 \\
(0.02)\end{array}$ & Ln Trend $\left(-1^{b}\right)$ & 0.13 & $\begin{array}{c}2.33 \\
(0.02)\end{array}$ & Ln GP & 0.011 & $\begin{array}{c}1.34 \\
(0.18)\end{array}$ \\
\hline Ln Trend $\left(-1^{b}\right)$ & 0.13 & $\begin{array}{c}2.33 \\
(0.02)\end{array}$ & Ln Trend $\left(-2^{b}\right)$ & -0.12 & $\begin{array}{l}-2.56 \\
(0.01)\end{array}$ & $\operatorname{Ln} G P\left(-1^{b}\right)$ & 0.016 & $\begin{array}{l}-1.91 \\
(0.05)\end{array}$ \\
\hline ln Trend $\left(-2^{b}\right)$ & -0.009 & $\begin{array}{l}-2.56 \\
(0.01)\end{array}$ & Ln DP & -0.02 & $\begin{array}{c}1.43 \\
(0.06)\end{array}$ & Ln Trend & 0.001 & $\begin{array}{c}0.06 \\
(0.04)\end{array}$ \\
\hline $\ln \mathrm{DP}$ & -0.008 & $\begin{array}{c}1.43 \\
(0.06)\end{array}$ & DUM & -0.24 & $\begin{array}{c}2.24 \\
(0.02)\end{array}$ & Ln DP & -0.015 & $\begin{array}{c}-1.9 \\
(0.05)\end{array}$ \\
\hline DUM & -0.24 & $\begin{array}{c}2.24 \\
(0.02)\end{array}$ & Ln Wind & -0.44 & $\begin{array}{l}-5.04 \\
(0.00)\end{array}$ & DUM & -0.03 & $\begin{array}{c}0.38 \\
(0.69)\end{array}$ \\
\hline Ln Wind & -0.11 & $\begin{array}{c}2.5 \\
(0.01)\end{array}$ & & & & Ln Wind & -0.09 & $\begin{array}{c}2.5 \\
(0.01)\end{array}$ \\
\hline Holi & -0.11 & $\begin{array}{c}3.05 \\
(0.00)\end{array}$ & Holi & -0.07 & $\begin{array}{c}0.2 \\
(0.3)\end{array}$ & Holi & -0.09 & $\begin{array}{c}3.24 \\
(0.01)\end{array}$ \\
\hline $\mathrm{C}$ & 8.001 & $\begin{array}{l}0.98 \\
(0.3)\end{array}$ & $\mathrm{C}$ & 9.1 & $\begin{array}{c}0.5 \\
(0.2)\end{array}$ & $\mathrm{C}$ & -7.44 & $\begin{array}{l}-0.95 \\
(0.33)\end{array}$ \\
\hline Diagn & stic tests & & Diagn & stic tests & & Diagn & ostic tests & \\
\hline & statics & $\mathrm{p}$ & & statics & $p$ & & statics & $\mathrm{p}$ \\
\hline $\mathrm{R}^{2}$ & 0.80 & - & $\mathrm{R}^{2}$ & & - & $\mathrm{R}^{2}$ & 0.80 & - \\
\hline $\begin{array}{l}\text { Durbin-Watson } \\
\text { stat }\end{array}$ & 2.05 & - & $\begin{array}{l}\text { Durbin-Watson } \\
\text { stat }\end{array}$ & 2.01 & & $\begin{array}{l}\text { Durbin-Watson } \\
\text { Stat }\end{array}$ & 1.91 & \\
\hline $\begin{array}{c}\text { Autocorrelation } \\
\text { test }\end{array}$ & 078 & 0.66 & $\begin{array}{c}\text { Autocorrelation } \\
\text { test }\end{array}$ & 0.68 & 0.76 & $\begin{array}{c}\text { Autocorrelation } \\
\text { test }\end{array}$ & 0.72 & 0.48 \\
\hline $\begin{array}{c}\text { Ramsey's } \\
\text { RESET Test }\end{array}$ & 0.59 & 0.44 & $\begin{array}{c}\text { Ramsey's } \\
\text { RESET Test }\end{array}$ & 0.4 & 0.54 & $\begin{array}{c}\text { Ramsey's } \\
\text { RESET Test }\end{array}$ & 0.74 & 0.46 \\
\hline Jarque -Bera & 1.77 & 0.41 & Jarque -Bera & 1.23 & 0.52 & Jarque -Bera & 1.65 & 0.39 \\
\hline $\begin{array}{c}\text { Engle's ARCH } \\
\text { LM }\end{array}$ & 0.64 & 0.42 & $\begin{array}{c}\text { Engle's ARCH } \\
\text { LM }\end{array}$ & 0.74 & 0.39 & $\begin{array}{c}\text { Engle's ARCH } \\
\text { LM }\end{array}$ & 1.19 & 0.27 \\
\hline
\end{tabular}

${ }^{\text {a }} \mathrm{P}$ value; ${ }^{\mathrm{b}}$ lag number

In model with $\mathrm{PM}_{10}$ dependent variable, the optimum lag for variables "Ln Temp" and "Ln Trend" were 1 and 2 respectively, so in this model we apply "Ln Temp (-1)", "Ln Trend (-1)", and "Ln Trend (-2)". In other hand, the optimum 
lag for other explanatory variables was zero, so we included these variables in non-lag form.

Also, in model with $\mathrm{NO}_{2}$ dependent variable, the optimum lag for variables "Ln VAT", "Ln MPI", and "Ln GP" were two, one, and one, respectively. Therefore, in this model we apply "Ln VAT", "Ln VAT (-1)", "Ln VAT (-2)", "Ln MPI (-1)", and "Ln GP (-1)". In other hand, the optimum lag for other explanatory variables was zero, so we included these variables in non-lag form.

The findings on dynamic models (short- term) showed that change in gasoline fuel price has greater impact on CO concentration than other pollutants. According to the results of short run, one percent change in gasoline fuel prices lead to $0.02,0.012$, and 0.011 percent change in $\mathrm{CO}, \mathrm{PM}_{10}$, and $\mathrm{NO}_{2}$ concentrations, respectively. Also, one percent increase in diesel fuel prices lead to $0.008,0.02$, and 0.015 percent decrease in $\mathrm{CO}, \mathrm{PM}_{10}$, and $\mathrm{NO}_{2}$ concentrations, respectively. The findings indicated that diesel price had greater impact on $\mathrm{NO}_{2}$ and $\mathrm{PM}_{10}$ concentrations and gasoline fuel price had greater impact on $\mathrm{CO}$ concentration than diesel fuel.

The findings on weather variables revealed that rainfall had no significant impacts on $\mathrm{CO}$ and $\mathrm{NO}_{2}$ concentrations. However, rainfall had a significant negative impact on $\mathrm{PM}_{10}$ concentration. Higher temperature was also associated with less air pollution. Wind blow had a significant effect on the concentration of all pollutants, and this relationship was inverse. That is one percent increase in wind speed resulted in $0.11,0.09$, and 0.44 percent decrease in the concentration of $\mathrm{CO}, \mathrm{NO}_{2}$, and $\mathrm{PM}_{10}$, respectively.

The findings revealed that time trend had positive impacts on $\mathrm{CO}$ and $\mathrm{NO}_{2}$ concentrations in a significant manner but no significant effect on $\mathrm{PM}_{10}$ concentration was observed. In other words, an increase in the population and change in fuel quality led to an increase in concentrations of $\mathrm{CO}$ and $\mathrm{NO}_{2}$.

The findings also indicated that coefficient of log VAT and MPI had positive impacts on air pollutant concentration, but not a significant effect.

In regards to the holidays, the findings indicated that an increase in number of holidays and weekends in each month had a negative impact on the concentrations of $\mathrm{CO}, \mathrm{NO}_{2}$, and $\mathrm{PM}_{10}$; so that, one percent increase in the number of holidays in each month, led to $0.11,0.09$, and 0.07 percent decrease in $\mathrm{CO}, \mathrm{NO}_{2}$, and $\mathrm{PM}_{10}$ concentration, respectively. However, this effect was not significant for $\mathrm{PM}_{10}$ concentration.

In this study the coefficient of determination $\left(R^{2}\right)$ in all models was near $1.00\left(R^{2}=0.8\right)$, which indicates that the models had a relatively high explanatory power. Also, the Durbin-Watson statistics in all three models were near two, which mean no autocorrelation problem was present in the models.

This study implemented several diagnostic tests to ensure models appropriateness, such as 1-test for the correctly specified model (Ramsey's RESET Test), 2- serial correlation (LM test), 3-heteroscedasticity (ARCH test) and 4normality (Jarque -Bera $(\mathrm{N})$ ). The diagnostic tests results showed that there are no problems associated with the correctly specified model, serial correlation, normality or heteroscedasticity. Table 3 shows the results of the dynamic equation estimation for three pollutants in three columns along with several diagnostic tests to ensure the accuracy of estimation models.

Furthermore, this study conveyed cumulative sum control chart (CUSUM) test to investigate stability of the model's coefficients. In this test, the confidence interval is two straight lines that show $95 \%$ confidence level. If the test statistics were located between these two lines, then the null hypothesis would not be rejected $\left(\mathrm{H}_{0}\right.$ : stability of 
parameters). The findings of this test indicated that all estimated parameters were stable at $5 \%$ significant level. Based on Figure 3, value for the CUSUM tests in all models were located between these two lines, which indicates the stability of the parameters in all models.

Also, The Boundary test was used to investigate existence of cointegration and the long- term relationship between variables. In this method, two critical bounds are presented, upper bound for time series I(1) and lower bound for series I(0). In this test, if the F statistic is greater than the upper bound value, the null hypothesis (lack of cointegration) is rejected; and if $\mathrm{F}$ statistic is less than the lower bound value, the null hypothesis is confirmed. Moreover, if the F statistic locates between two bounds, no conclusions can be made. Results of boundary test showed that $\mathrm{F}$ statistic is higher than upper bound, which is provided by Pesaran et al. consequently, there is a longterm relationship between variables. Table 4 shows the results of Boundary test for models.

The long - term results of the models showed that, one percent increase in gasoline fuel price lead to 0.027 and 0.016 percent decrease in concentrations of $\mathrm{CO}$ and $\mathrm{PM}_{10}$, respectively; and 0.02 percent increase in $\mathrm{NO}_{2}$ concentration. However, the impact on $\mathrm{PM}_{10}$ was not significant in the long term. Furthermore, one percent increase in diesel fuel price leads to $0.011,0.024$, and 0.029 percent decrease in concentrations of $\mathrm{CO}, \mathrm{NO}_{2}$, and $\mathrm{PM}_{10}$, respectively. Therefore, in the long term, fuel price changes had a greater impact on the concentrations of pollutants compared to the short run. In the short term however, changes in gasoline fuel prices had greater impact on the concentration of pollutants, than diesel fuel prices.

Table 4. Boundary test results for the models

\begin{tabular}{llccc}
\hline \multicolumn{2}{c}{ F-statistic } & & & \multicolumn{2}{c}{ critical bounds at 5\% Significant level } \\
\cline { 5 - 5 } Model with $\mathrm{PM}_{10}$ dependent variable & 5.14 & & 2.01 & 3.05 \\
\hline Model with $\mathrm{NO}_{2}$ dependent variable & 4.98 & & 2.01 & 3.05 \\
\hline Model with $\mathrm{CO}$ dependent variable & 6.15 & & 2.01 & 3.05 \\
\hline
\end{tabular}

Other variables such as VAT and MPI had a positive impact on the concentration of all air pollutants in significant manner. So that one percent increase in VAT causes a $0.31,0.31$, and 1.21 percent increase in $\mathrm{CO}, \mathrm{NO}_{2}$, and $\mathrm{PM}_{10}$ concentrations, respectively. Also, one percent increase in MPI causes a 2.96, 2.96, and 0.88 percent increase in CO, $\mathrm{NO}_{2}$, and $\mathrm{PM}_{10}$ concentrations, respectively. Consequently, these two variables had greater impacts in the long term compared to the short term.

For other coefficients related to weather variables, the findings revealed that rainfall, wind blow, and temperature had no significant impacts on pollutant concentration except for $\mathrm{PM}_{10}$. That is one percent increase for rainfall and temperature leads to 0.01 percent decrease in $\mathrm{PM}_{10}$ concentration in the long term. The stated coefficients were greater in the long term than for the short term.

The findings also indicated that time trend had maximum impacts on all pollutant concentrations in the long- term. This means the increase in the population and decrease in fuel quality in the long- term, lead to $1.78,1.93$, and 0.05 percent increase in $\mathrm{CO}, \mathrm{NO}_{2}$, and $\mathrm{PM}_{10}$ concentration respectively. Table 5 shows the results of long- term relationship between variables for models with three different dependent variables (i.e. $\mathrm{CO}, \mathrm{NO}_{2}$, and $\mathrm{PM}_{10}$ ).

Table 5. Results of long-term estimations for models with three different pollutants $\left(\mathrm{CO}, \mathrm{NO}_{2}\right.$, and $\left.\mathrm{PM}_{10}\right)$ 


\begin{tabular}{cccc}
\hline & \multicolumn{3}{c}{ Model with dependent variable: } \\
\cline { 2 - 4 } & Ln CO & Ln $\mathrm{NO}_{2}$ & Ln $\mathrm{PM}_{10}$ \\
\cline { 2 - 4 } Variable & Coefficient (p) & Coefficient (p) & Coefficient (p) \\
\hline Ln DP & $(0.002) 0.011-$ & $(0.002) 0.024-$ & $(0.03) 0.029-$ \\
Ln GP & $-0.027(0.01)$ & $0.02(0.01)$ & $-0.016(0.27)$ \\
\hline Ln MPI & $(0.007) 2.96$ & $(0.007) 2.96$ & $(0.001) 0.88$ \\
\hline Ln Rain & $(0.62) 0.008$ & $(0.62) 0.008$ & $(0.01) 0.01-$ \\
\hline Ln Temp & $-0.07(0.14)$ & $-0.07(0.14)$ & $(0.05) 0.01-$ \\
\hline Ln Wind & $-0.1(0.1)$ & $-0.52(0.2)$ & $(0.06) 1.07-$ \\
\hline Ln VAT & $(0.05) 0.31$ & $(0.05) 0.31$ & $1.21(0.01)$ \\
\hline Ln Trend & $(0.01) 1.78$ & $(0.01) 1.93$ & $(0.00) 0.05$ \\
\hline Holi & $(0.04) 0.8-$ & $(0.07) 0.8-$ & $(0.07) 0.92-$ \\
\hline DUM & $(0.5) 1.1-$ & $(0.5) 1.0-$ & $(0.4) 0.93-$ \\
\hline C & $(0.49) 10.91-$ & $(0.49) 10.91-$ & $(0.3) 16.15-$ \\
\hline
\end{tabular}

\subsection{Sub-period analysis gasoline-Compressed Natural Gas (CNG) substitution}

Over the past decade, the Iranian government has paid a lot of attention to the production of CNG vehicles in order to reduce gasoline consumption and air pollution. As part of such plan, gasoline-fueled vehicles have been converted to CNG and, the number of CNG stations has been increased around the nation. However, the CNG-fueled vehicles emit less $\mathrm{CO}$ and more $\mathrm{NO}_{2}$ than the gasoline powered vehicles. In order to increase the validity of the results, the models were studied in two different periods - during 01. 2009- 03.2013 (period 1) and 04. 2013-12.2019 (period 2) (Table 6).

Results showed that an increase in gasoline price leads to an increase in $\mathrm{NO}_{2}$ concentration in recent years and the second period of study as well. Based on substitution between gasoline and CNG, an increase in gasoline fuel price lead to increases in $\mathrm{CNG}$ consumption and consequently increases $\mathrm{NO}_{2}$ emission.

Table 6. Fuel price affects $\mathrm{CO}, \mathrm{NO}_{2}$, and $\mathrm{PM}_{10}$ during period (1) and period (2)

\begin{tabular}{|c|c|c|c|c|c|c|}
\hline \multirow{3}{*}{ Variable } & \multicolumn{6}{|c|}{ Model with dependent variable } \\
\hline & \multicolumn{2}{|c|}{$\mathrm{CO}$} & \multicolumn{2}{|c|}{$\mathrm{NO}_{2}$} & \multicolumn{2}{|c|}{$\mathrm{PM}_{10}$} \\
\hline & Period 1 & Period 2 & Period 1 & Period 2 & Period 1 & Period 2 \\
\hline Ln DP & -0.02 & -0.018 & -0.019 & -0.019 & -0.26 & -0.027 \\
\hline Ln GP & -0.02 & -0.029 & -0.016 & 0.014 & -0.016 & -0.019 \\
\hline $\mathrm{R}^{2}$ & 0.8 & 0.8 & 0.8 & 0.79 & 0.81 & 0.81 \\
\hline
\end{tabular}

\section{Discussion}

Tehran, as a megacity and capital of Iran, has been dealing with air pollution problems for years; problems largely originated from high traffic density, and gases emitted from all kinds of vehicles. This study focused on the effect of fuel prices and weather on concentration of $\mathrm{CO}, \mathrm{NO}_{2}$, and $\mathrm{PM}_{10}$ as main pollutants that are emitted from fossil fuel consumption in transport sectors.

The findings of the present study showed that the trend of CO and PM10 concentration in Tehran was diminishing over the investigated period; but $\mathrm{NO}_{2}$ had an increasing trend. Expanding the culture of using subway and public transportation, and promoting vehicles with a Euro 2 standard or higher, has played a key role in the downward trend 
of CO and PM10 concentrations (19). Also, replacing the consumption of vehicles' fuel from gasoline to CNG plays an important role on the increasing trend of $\mathrm{NO}_{2}$ concentration $(20,21)$.

In a review study done in developing and developed countries , Baldasano et al showed that the trend of $\mathrm{PM}_{10}$ and CO concentration levels were declining (22). While, the study conducted in Korea, showed that CO and PM10 concentration had an increasing trend and $\mathrm{NO}_{2}$ had no clear and steady trend (23).

Overall, our results showed that fuel prices have significant negative impacts on $\mathrm{CO}$ and $\mathrm{PM}_{10}$ concentration for both short and long term. The increase in gasoline and diesel prices leads to decrease in $\mathrm{CO}$ and $\mathrm{PM}_{10}$ concentrations. Increase in the gasoline and diesel price, as the main price policies to control air pollution, reduces fuel consumption. Since high consumption of fuel in transport section of the country is one of the main contributors to air pollutants emission, reducing the consumption of these carriers results in reduction of pollutant emission and consequently concentration of pollutants.

In contrast to other pollutants, gasoline price had positive impact on $\mathrm{NO}_{2}$ concentration. Increasing government investments in using clean fuels such as CNG and increase in the number of CNG-fueled vehicles, results in increased demand for CNG due to rising gasoline prices. Since the CNG use has a higher $\mathrm{NO}_{2}$ emission rate than other fuels, the increase in gasoline prices was associated with increased emission and concentration of $\mathrm{NO}_{2}$. $\mathrm{These}$ results are consistent with the results of the Ninpanit study (12).

In a study conducted in New Zealand, Shaw et al showed $1 \%$ increase in gasoline price was associated with a $0.32 \%$ $(-1.21$ to 0.58$)$ reduction in $\mathrm{NO}_{2}$ concentration in short term (24). Although, in another study that was conducted in Brisbane, Brannet showed that changes in petrol prices had no impact on air pollution (13). In a study conducted by Heger et al in Cario, results showed that $30 \%$ and $80 \%$ increase in fuel price lead to the overall decline in traffic, and consequently $1.6 \%$ and $2.3 \%$ decrease in $\mathrm{PM}_{10}$ concentration (25).

Also, results showed that changes in gasoline price had a greater impact on CO concentration compared to $\mathrm{NO}_{2}$ and $\mathrm{PM}_{10}$ concentrations. Considering that, the volume of $\mathrm{CO}$ pollutant emitted by gasoline-powered vehicles is higher than $\mathrm{NO}_{2}$ and $\mathrm{PM}_{10}$; increase in gasoline prices will result in a greater reduction in $\mathrm{CO}$ concentration compared to other pollutants. These results are consistent with the findings of other studies $(12,26)$.

On the other hand, as nearly as $80 \%$ of the $\mathrm{PM}_{10}$ emission created in the transportation sector comes from dieselpowered vehicles (27). Therefore, increasing the diesel fuel price and reducing its consumption proportionally, causes a further reduction in emissions and pollution of $\mathrm{PM}_{10}$. A study conducted by Ninpanit showed that one percent increase in gasoline price leads to $0.36 \%$ decrease in $\mathrm{CO}$ concentration, while $1 \%$ increase in gasoline price leads to $0.23 \%$ and $0.25 \%$ change in $\mathrm{NO}_{2}$ and $\mathrm{PM}_{10}$ concentrations respectively (12).

The comparison of the findings on short and long -term models revealed that an increase in fuel prices had greater impacts for diminishing the pollutants concentration in the long term compared to the short term. These findings were consistent with Mousavi et al and Ninpanit findings $(12,28)$. In a time series study conducted by Mousavi et al, results showed that $1 \%$ increase in fuel price leads to $0.06 \%$ and $0.14 \%$ decrease in CO concentration in short and long term respectively (28). Researchers believe that introduction of optimum fuel technologies in the transport sector, improvement of public transportation system and expanding the usage of hybrid or low-power vehicles in the long term, leads to a significant reduction in fuel consumption. In addition, rising fuel prices leads to reduction in 
emissions of pollutants caused by transporting vehicles. In the long term, people are also more capable of changing their pattern of fuel consumption, which results in more people's capability to respond to fuel price policies $(29,30)$.

Comparison of estimated fuel prices coefficients with the other coefficients revealed that the fuel policies had lower impact on air pollutants concentration. In other words, weather status and other variables such as MPI and VAT had greater impacts on pollutants concentrations. An increase in economic growth, production, and consequently MPI require an increase in fuel consumption. On the other hand, due to the low productivity and efficiency of industries, increasing MPI lead to greater increases in fuel consumption and consequently greater pollutants emission. Hence, policy makers should try to enhance the utilization efficiency of inputs, such as fuels, to maintain production and finally reduce the growth of emission pollutants $(31,32)$. Also, many studies have revealed the role of meteorological conditions on air pollution $(33,34)$. Results of a study conducted by Ma et al in the Yangtze River Delta (YRD) region in China showed that meteorological conditions mainly influence day-to-day variations in pollutant concentrations. $\mathrm{PM}_{2.5}$ concentration was inversely related to wind speed, while concentrations of other pollutants was negatively correlated with relative humidity and positively correlated with temperature (35). In conditions such as increased relative humidity of the air accompanied by the phenomenon of rainfall, the washing operation can reduce air pollutants concentrations.

Also, the findings of the present study revealed that rising number of holidays and weekends had a significant effect on decreasing the concentrations of pollutants. This fact is evident in paternal changes of vehicular usage of individuals in weekends and holidays. Most people do not use personal vehicle on weekends or holidays because of

the shutdown of schools and offices. In two studies conducted by Bahreini et al and Harley et al, results showed that emissions from fuel consumption could be reduced by $60-80 \%$ on the weekends due to reductions in road traffic $(36,37)$.

This study has limitations. Lack of access to air pollution data before 2009 considered one of the study limitations. So, the study period was limited to after 2009. Also, due to incomplete data in the air pollution monitoring station, finally, we gathered air pollution data from 19 out of 22 monitoring station in Tehran. Also, Sulfur dioxide $\left(\mathrm{SO}_{2}\right)$ was another most pollutant emitted from the transportation sector in Tehran. However, since many monitoring stations did not record this pollutant, it was not possible to study the effect of price policies on the concentration of $\mathrm{SO}_{2}$ in this study.

\section{Conclusion}

The results of this study showed that the pollutants concentrations in Tehran have been decreasing in general, however, this trend has been increasing for some pollutants or in some districts in this city. According to the extracted results from study models, fuel pricing policies reduce the concentration of pollutants that are emitted from the transport sector in the long and short term. However, considering the impact of other factors, increase in gasoline and diesel prices had low impact on Tehran's air pollution concentration. In other words, weather and economic conditions, as well as improved technology, have a greater impact on the concentration of pollutants than fuel prices. Therefore, focus on policies such as improved technology and enhancing the quality of fuel can be more effective.

Also, given the different impact of gasoline and diesel prices, increase in the price of energy carriers requires paying attention to their relative prices. Therefore, unbalanced and dissimilar increase in prices can lead to fuels substitution. This will lead to an increase in alternative and cheaper fuel consumption and ultimately increase in related pollutants.

Page $12 / 16$ 


\section{Abbreviations}

CO: Carbon monoxide, $\mathrm{NO}_{2}$, Nitrogen dioxide, $\mathrm{PM}_{10}$ : Particular matter 10 micrometers or less

\section{Declarations}

\section{Ethics approval and consent to participate}

No applicable.

\section{Consent for publication}

No applicable.

\section{Availability of data and materials}

The datasets generated and analyzed for this study are not publicly available due to participant privacy but are available from the corresponding author upon reasonable request.

\section{Competing interest}

The authors declare that they have no conflict of interest.

\section{Funding}

This work has no financial support.

\section{Author contributions}

THK had the idea for the article, MH and PR performed data analysis, and THK performed drafted and critically revised. SA performed data gathering. All authors reviewed and approved the final manuscript.

\section{Acknowledgements}

We thank Iran University of Medical Sciences for financial supports.

\section{References}

1. Piraino F, Aina R, Palin L, Prato N, Sgorbati S, Santagostino A, et al. Air quality biomonitoring: Assessment of air pollution genotoxicity in the Province of Novara (North Italy) by using Trifolium repens L. and molecular markers. Science of the Total Environment. 2006;372(1):350-9.

2. Scorer RS. Pollution in the air: problems, policies and priorities: Routledge; 2019.

3. Mohan M, Kandya A. An analysis of the annual and seasonal trends of air quality index of Delhi. Environmental monitoring and assessment. 2007;131(1-3):267-77.

4. Baklanov A, Grimmond CSB, Carlson D, Terblanche D, Tang X, Bouchet V, et al. From urban meteorology, climate and environment research to integrated city services. Urban Climate. 2018;23:330-41.

5. Hosseini V, Shahbazi H. Urban air pollution in Iran. Iranian Studies. 2016;49(6):1029-46. 
6. Atash F. The deterioration of urban environments in developing countries: Mitigating the air pollution crisis in Tehran, Iran. Cities. 2007;24(6):399-409.

7. Heger M, Sarraf M. Air pollution in Tehran: health costs, sources, and policies: World Bank; 2018.

8. Douglas MJ, Watkins SJ, Gorman DR, Higgins M. Are cars the new tobacco? Journal of Public Health. 2011;33(2):160-9.

9. World Bank. Air Pollution in Tehran : Health Costs, Sources, and Policies. Washington, D.C: World Bank Group; 2018.

10. Hajihoseinlou M, Karooni A. Evaluation of Traffic Management Policies for Reducing Air Pollution in Tehran. 3th Regional Conference on Traffic Management; Tehran2007.

11. Delsalle J. The effects of fuel price changes on the transport sector and its emissions-simulations with TREMOVE. Directorate General Economic and Financial Affairs (DG ECFIN), European ...; 2002.

12. Ninpanit P. The effects of fuel prices on air quality: Evidence from Bangkok Metropolitan Region. 2019.

13. Barnett AG, Knibbs LD. Higher fuel prices are associated with lower air pollution levels. Environment international. 2014;66:88-91.

14. Statistical Center of Iran. 2020 [Available from: https://www.amar.org.ir/english/Iran-StatisticalYearbook/Statistical-Yearbook-2016-2017.

15. Hensel M, Gharleghi M. Iran: past, present and future: John Wiley \& Sons; 2012.

16. Pesaran $\mathrm{MH}$, Shin Y, Smith RJ. Bounds testing approaches to the analysis of level relationships. Journal of applied econometrics. 2001;16(3):289-326.

17. Creamean JM, Suski KJ, Rosenfeld D, Cazorla A, DeMott PJ, Sullivan RC, et al. Dust and biological aerosols from the Sahara and Asia influence precipitation in the western US. science. 2013;339(6127):1572-8.

18. Bhaskar BV, Mehta VM. Atmospheric particulate pollutants and their relationship with meteorology in Ahmedabad. Aerosol Air Qual Res. 2010;10(4):301-15.

19. Sanie R, Zangiabadi A, Sharifi kia M. The analysis of daily trend of air pollutants in Tehran metropolis. Geography. 2017;15(54 \#B0080):-.

20. Krittayakasem P, Patumsawad S, Garivait S. Emission inventory of electricity generation in Thailand. Journal of Sustainable Energy \& Environment. 2011;2(2):67.

21. Yilmaz I, Gumus M. Investigation of the effect of biogas on combustion and emissions of TBC diesel engine. Fuel. 2017;188:69-78.

22. Baldasano J, Valera E, Jimenez P. Air quality data from large cities. Science of the Total Environment. 2003;307(1-3):141-65.

23. Kim J, Ghim YS, Han J-S, Park S-M, Shin H-J, Lee S-B, et al. Long-term Trend Analysis of Korean Air Quality and Its Implication to Current Air Quality Policy on Ozone and PM 10. Journal of Korean Society for Atmospheric Environment. 2018;34(1):1-15.

24. Shaw C, Hales S, Edwards R, Howden-Chapman P, Stanley J. What can fuel price increases tell us about the air pollution health co-benefits of a carbon price? Journal of Transport \& Health. 2018;8:81-90.

25. Heger M, Wheeler D, Zens G, Meisner C. Motor Vehicle Density and Air Pollution in Greater Cairo: Fuel Subsidy Removal and Metro Line Extension and Their Effect on Congestion and Pollution. World Bank; 2019.

26. Delangizan S, Khanzadi A, Heideryan M. Studying the effects of fuel price changes on greenhouse gas emissions in the road transportation sector of Iran; new approach of robust least squares. Journal of Quantitative Economics (Quarterly Journal of Economics Review). 2015;11(4 (43)):-.

Page 14/16 
27. Ministry of Energy. Energy balance sheet. In: Office PaEP, editor.: Ministry of Energy; 2018.

28. Mousavi S, Mozaffari Z, Motamed M. The effect of higher fuel price on pollutants emission in Iran. Caspian Journal of Environmental Sciences. 2018;16(1):1-10.

29. Taheri $\mathrm{E}$, sadeghi $\mathrm{H}$, assari arani a. Effect of Increases in Energy Carriers' Prices on the Degradation Cost of Air Pollutants in Iran: Computable General Equilibrium Approach. The Economic Research. 2017;17(3):131-57.

30. Manzour D, Haghighi I. Impact of Energy Price Reform on Environmental Emissions; a Computable General Equilibrium Approach. Journal of Environmental Studies. 2012;37(60):1-12.

31. Shapiro JS, Walker R. Why is pollution from US manufacturing declining? The roles of trade, regulation, productivity, and preferences. US Census Bureau Center for Economic Studies Paper No CES-WP-15-03. 2015.

32. Biswas AK, Farzanegan MR, Thum M. Pollution, shadow economy and corruption: Theory and evidence. Ecological Economics. 2012;75:114-25.

33. Yang J, Kang S, Ji Z, Yin X, Tripathee L. Investigating air pollutant concentrations, impact factors, and emission control strategies in western China by using a regional climate-chemistry model. Chemosphere. 2020;246:125767.

34. Guo MM, Jiang N, Wang SB, Duan SG, Zhang RQ. [Analysis of Air Pollution Characteristics and Meteorological Conditions in Zhengzhou from 2014 to 2017]. Huan Jing Ke Xue. 2019;40(9):3856-67.

35. Ma T, Duan F, He K, Qin Y, Tong D, Geng G, et al. Air pollution characteristics and their relationship with emissions and meteorology in the Yangtze River Delta region during 2014-2016. J Environ Sci (China). 2019;83:8-20.

36. Bahreini R, Middlebrook A, De Gouw J, Warneke C, Trainer M, Brock C, et al. Gasoline emissions dominate over diesel in formation of secondary organic aerosol mass. Geophysical Research Letters. 2012;39(6).

37. Harley RA, Marr LC, Lehner JK, Giddings SN. Changes in Motor Vehicle Emissions on Diurnal to Decadal Time Scales and Effects on Atmospheric Composition. Environmental Science \& Technology. 2005;39(14):5356-62.

\section{Figures}

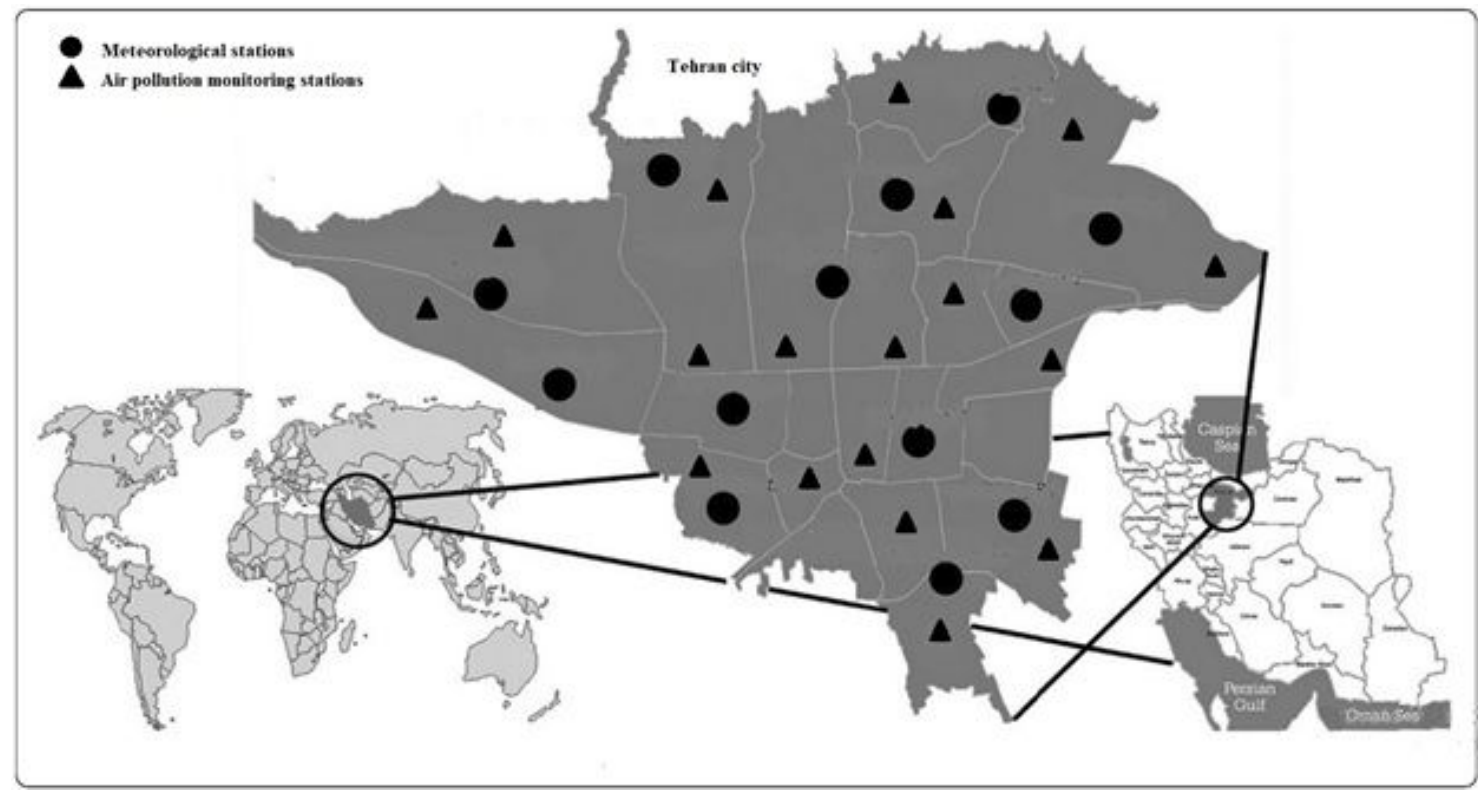

Figure 1 
Map of the study area and the location of the stations

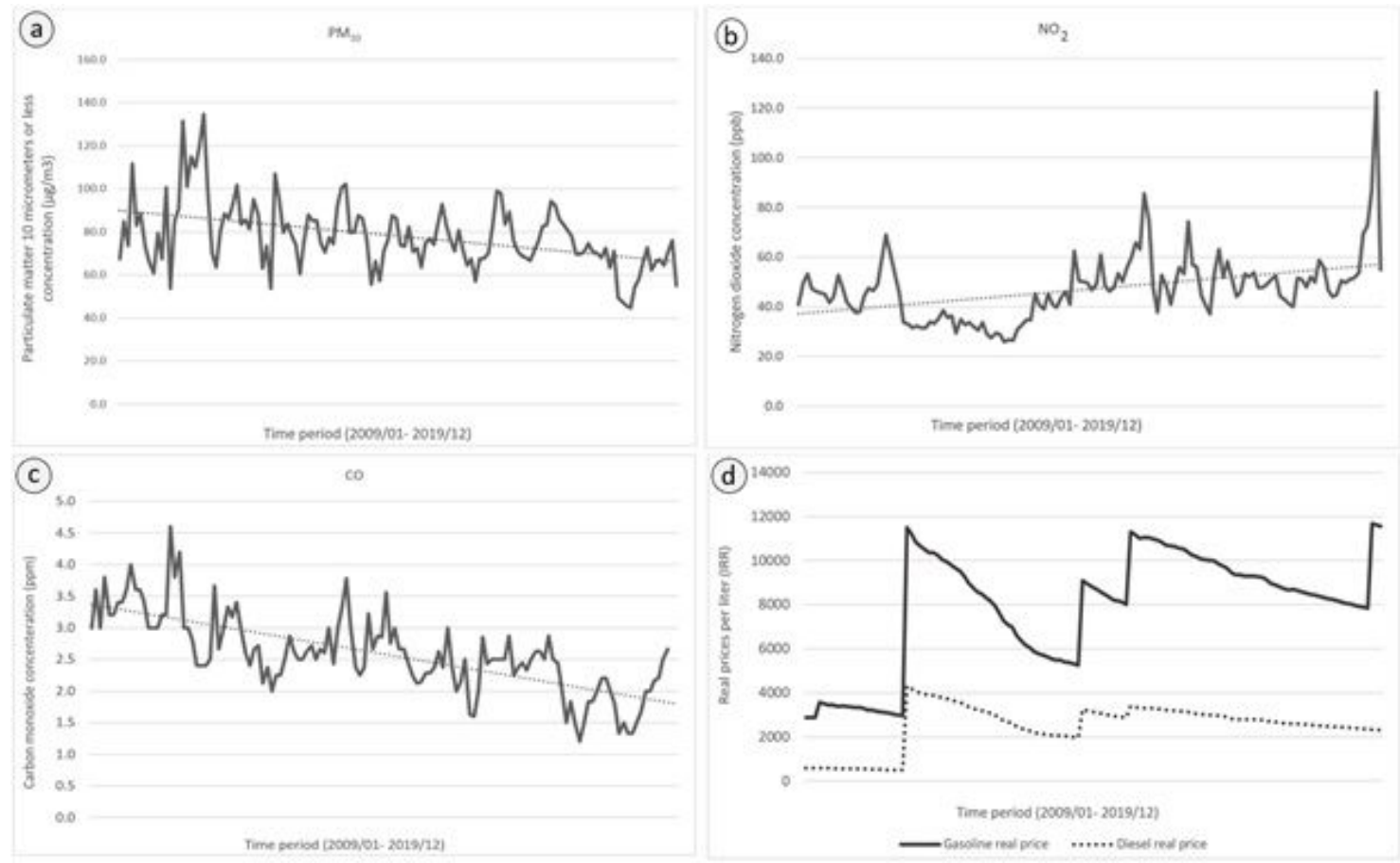

\section{Figure 2}

Monthly average concentration of PM10, NO2, CO (a-c) and monthly average of fuel prices (d) in Tehran during 03. 21. 2009 to 12.21 .2019
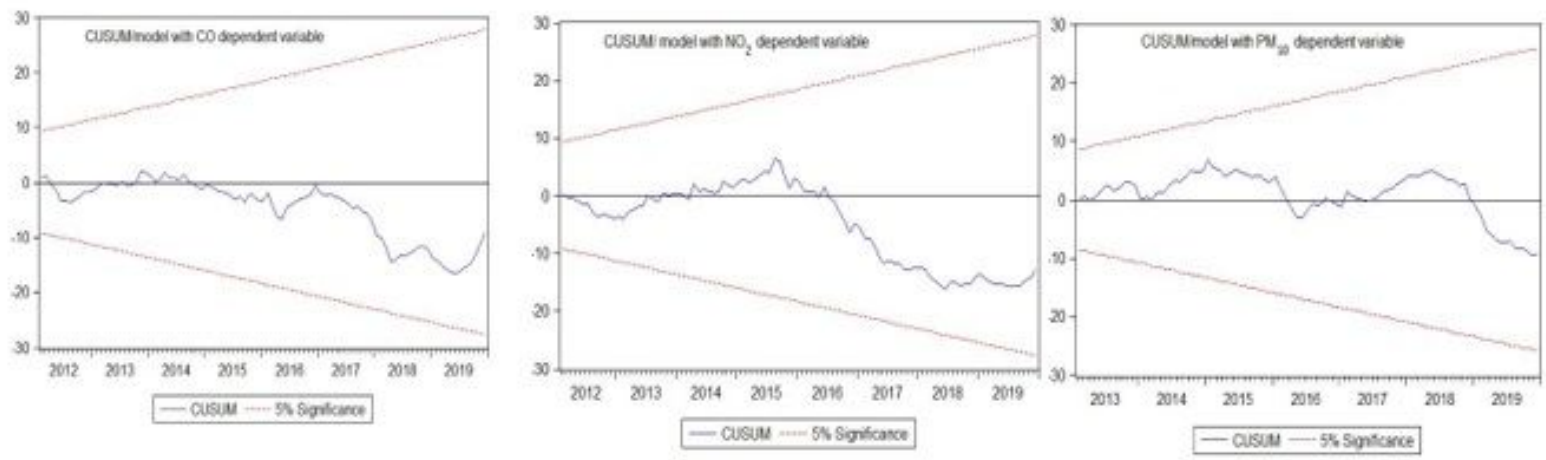

Figure 3

Results of CUSUM tests for models

\section{Supplementary Files}

This is a list of supplementary files associated with this preprint. Click to download.

- Equation.pdf 